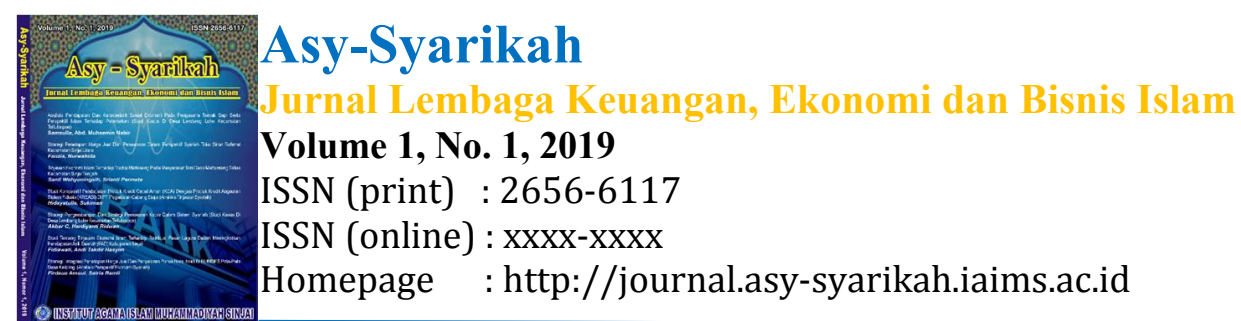

\title{
STRATEGI PENGEMBANGAN DAN STRATEGI PEMASARAN KOPRA DALAM SISTEM SYARIAH
}

(Studi Kasus Didesa Lembang Lohe Kecamatan Tellulimpoe)

\author{
Akbar, Hardiyanti Ridwan \\ Institut Agama Islam Muhammadiyah Sinjai \\ E-mail/Tlp:hardiyantiridwan@gmail.com/085215505660
}

\begin{abstract}
Abstrak
Penelitian dilakukam untuk mendapatkan data yang diperlukan serta menguraikan secara sederhana semua permasalahan yang menyangkut hal-hal yang berkaitan dengan skripsi ini mengenai Strategi penegembangan dan strategi pemaaran kopra dalam sistem Syariah maka dapat disimpulkan bahwa Penelitian ini termasuk jenis penelitian kualitatif menggunakan jenis pendekatan naturalistic yang dikumpulkan dalam penelitian ini adalah berdasarkan persepsi dan pemikiran orang secara individual, yang melibatkan produksi kopra dan pedagang kopra sebagai subjek penelitian. Dan hasil penelitian diperoleh melalui wawancara dan dokumentasi kemudian data yang terkumpul berupa kata-kata dianalisa dengan tekhnik reduksi data, penyajian data dan penarikan kesimpulan. Hasil penelitian ini menyimpulkan bahwa : 1. Dalam startegi pemasaran, masyarakat mengelolah buah kelapa, menjadi suatu produk yang lebih mahal dibanding dengan, menjual kelapa mentah langsung. sistem pemasaran kopra yang dilakukan di desa lembang lohe kecamatan tellulimpoe adalah dengan memasarkan hasil produk kopra di pedagang pengumpul, dan pedagang pengumpul memasarkan lansung produksi kopra di pasar terdekat. 2. Sedangkan dari hasil penenlitian dapat disimpulkan bahwa sistem pengembangan dilakukan dengan cara harus memepertahankan sumber bahan baku yang ada di daerah sendiri, dan persediaan bahan baku selalu terpenuhi setiap ingin memproduksi kopra.
\end{abstract}

Kata kunci: pemasaran Kopra, Strategi Pemasaran Syariah

\section{Pendahuluan}

Indonesia merupakan satu di antara angaris yang kehidupan perekonomiannya tidak lepas dari sektor pertanian. Perkembangan ekonomi indonesia yang akhir-akhir ini cendrung mengalami pergeseran sektoral pertanian ke sektor non pertanian. Sektor pertanian tetap memegang peranan penting, karena berperang sebagai penyedia bahan pangan bagi seluruh masyarakat, di sisi lain menompang pertumbuhan industri dalam hal penyediaan bahan baku industri dan mendorong pemerataan pertumbuhan dan dinamika pedesaan. Indonesia dikenal sebagainegara tropis penghasil buah-buahan yang sangat dikenal oleh masyarakat internasionall, satu diantara hasil pertanian adalah kelapa.

Hampir semua kawasan di indonesia mudah di jumpai pohon kelapa yang penguasanya baik secara individual maupun berupa perkebunan rakyat. Pohon kelapa 


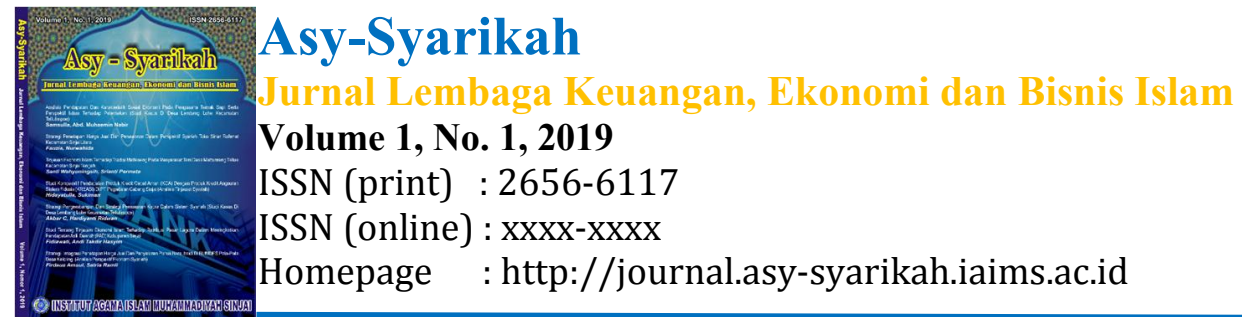

sering disebut đengan pohon kehidupan karena mempunyai manfaat yang tidak sedikit bagi kehidupan manusia. Hanya saja di indonesia pohon kelapa masi kalah pamor dengan kerabatnya, yaitu kelapa sawit, namun ditinjau dari ragam produk yang lebih beragam jenisnya dibandingkan dengan kelapa sawit.

Berapa jenis produk yang dihasilkan oleh kelapa yang tidak dapat ditemukan dalam kelapa sawit dianntaranya: santan, dula kelapa, dan lain-lain. Selain itu produk lainnya yang dapat diperoleh adalah kayu arang aktif. Serta berbagi kerajinan yang dihasilkan dengan mendayagunakan setiap bagian dari kelapa. Pembangunan pertanian bertujuan untuk meningkatkan hasil dan mutu tani, serta meningkatkan pendapatan dan taraf hidup petani. Upaya peningkatan usaha tani ini dilakukan antara lain melalui pasca panen, kebijakan harga yang layak bagi petani. Pengembangan dan pemanfaatan teknologi, serta penyediaan sarana dan prasarana produksi yang memadai.

Kopra merupakan putih lembaga dari buah kelapa segar yang dapat dikeringkan dengan metode konvensional mneggunakan sinar matahari langsung, pengeringan dengan pemanasan secara tidak langsung, dan pengeringan dengan udara vakum. Tataniaga kelapa pada umumnya memang perang penting atau merupakan faktor keberhasilan suatu usaha tani.

Berdasarkan hal tersebut maka penulis tertarik mengambil topik dalam penelitian ini adalah "Strategi Pengembangan dan Strategi Pemasaran Kopra dalam system syariah di Desa Lembang Lohe, Kecamatan Tellulimmpoe.'

Berdasarkan latar belakang yang telah penulis paparkan di atas, maka dapat dirumuskan permasalahan sebagai berikut:

a. Bagaimana strategi pengembangan kopra di Desa Lembang Lohe ?

b. Bagaimana strategi pemasaran kopra di Desa Lembang Lohe, Kecamatan Tellulimpoe?

\section{Tinjauan Pustaka}

\subsection{Pengertian Strategi Pengembangan}

Strategi adalah langkah-langkah yang harus dijalankan oleh suatu perusahaan untuk mencapai tujuan. Pengembangan usaha adalah tugas dan proses persiapan analisi tentang peluang pertumbuhan potensial, dukungan dan pemantauan peluang pertumbuhan usaha, tetapi tidak termasuk keputusan strategi dan implementasi dari peluang pertumbuhan usaha. 


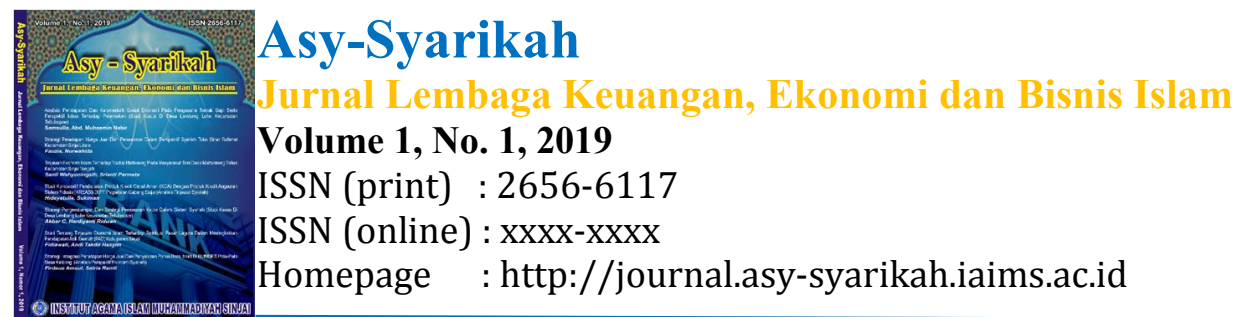

Strategi Pengembangan Bisnis merupakan keseluruhan usaha termasuk perencanaan, cara, teknik, media, dan taktik yang digunakan dalam mengembangkan bisnis sehingga tujuan usaha atau bisnis dapat tercapai.Dalam strategi mengembangkan usaha (ekspansi).

Untuk kepentingan strategi pengembangan pasar maka perlu dilakukan risetpemasaran, survey, dan analisa segmen pasar, target pembeli, dan perilaku pembeli. Jika ditinjau dari jenis pengembangannya maka bisa dibagi menjadi beberapa strategi, yaitu:Mengembangkan pasar dari sisi produknyaMengembangkan pasar dari sisi produk adalah langkah yang paling memungkinkan untuk dilakukan pertama kali karena produk utamanya telah diperkenalkan dan sudah tumbuh, sehingga masalah profitabilitas (kemampuan mendapatkan laba) serta popularitas dan kualitas sudah diterima dipasar.

\subsection{Tinjauan Tentang Pemasaran Kopra}

Ukuran keberhasilan perusahaan dalam menerapkan strategi pemasarannya adalah mampu memberikan kepuasan kepada pelanggang. Semakin banyak pelanggang yang menerima produk atau jasa yang ditawarkan, maka mereka semakin puas, dan ini berarti strategi yang dijalankan sudah cukup berhasil. Ukuran mampu meraih pelanggang sebanyak mungkin hanya merupakan salah satu ukuran bahwa strategi yang dijalankan sudah cukup baik. Masih ada lagi ukuran lainnya, misalnya tingkat laba yang diperoleh dan ukuran lainnya.

Strategi bauran pemasaran atau lebih dikenal dengan nama Marketing Mix Strategi, pelaksanaan ini dibagi kedalam : strategi produk, startegi harga, startegi lokasi dan distribusi, dan strategi peromosi.

a. Strategi produk

Unsur ini dalam bauran pemasaran sepenuhnya menguraikan sifat usaha wuraswawasstan kerena mungkin terdapat hanyak produk atau jasa tunggal pada awal usaha baru. Dalam unsur produk atau jasa terdapat variabel lain yang harus dipertimbangkan dalam rencana pemasaran, seperti kemasan, cap, pengembangan produk baru, dan desain produk ( termasuk bentuk dan warna ). Mutu dari strategi produk mempengaruhi strategi harga.Sebuah produk bermutu tinggi mungkin memerlukan harga yang tinggi untuk membangun prestise dipasar dan memenuhi persyaratan kinerja laba kerja manajemen.

b. Strategi harga

Penentuan harga merupakan satu keputusan yang paling sulit untuk suatu usaha baru adalah harga yang tepat untuk produk atau jasa.produk atau jasa mungkin ditetapkan pada 


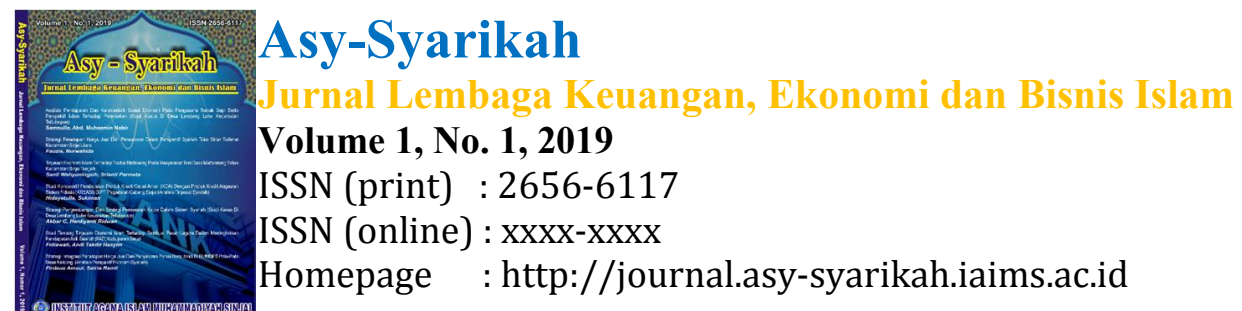

harga tinggi untuk mempertahankan citranya. Dalam keputusan penentuan harga, faktor lain harus dipertimbangkan seperti biaya, diskon, pengangkutan dan laba. Penetuan harga tergantung pada permintaan produk karena kemampuan untuk membeli bahan dalam jumlah besar mengurangi biaya.

c. Strategi tempat dan distribusi

Distribusi adalah cara perusahaan menyalurkan barangnya, melalui dari tangan perusahaan sampai ketangan konsumen akhir. Strategi distribusi penting dalam upaya perusahaan melayani konsumen tepat waktu dan tepat sasaran, keterlambatan dalam penyaluran mengakibatkan perusahaan kehilangan waktu dan kualitas barang serta diambilnya kesempatan oleh pasaing.

d. Strategi promosi

Promosi penjualan merupakan upaya khusus anda untuk meningkatkan penjualan.Sebuah promosi penjualan dapat berupa tawaran perkenalan khusus, potongan harga, demostrasi, peragaan, khusus, contoh-contoh gratis iklan khusus. Promosi merupakan kegiatan Marketing mix yang terkhitr. Kegiatan ini sama pentingnya dengan ketiga kiatan diatas, baik produk, harga, maupun distribusi. Dalam H ini kegiatan ini setiap perusahaan berusaha mempromosikan seluruh produk yang dimilianya, baik langsung maupun tidak langsung. Paling tidak ada empat macam sarana promosi yang dapat digunakan yaitu :

1) Periklanan

2) Promosi penjualan

3) Publisitas

4) Penjualan pribadi

\section{Konsep Inti Pemasaran}

Pemasaran adalah suatu proses sosial dan manajerial diman individu dan kelompok mendapatkan kebutuhan dan keinginan mereka dengan menciptakan, menawarkan dan bertukar sesuatu yang bernilai satu sama lain.

Devinisi ini berdasarkan pada konsep inti: kebutuhan, keinginan dan permintaan, produk nilai, biaya dan kepuasan, pertukaran, teransaksi, dan hubungan pasar dan pemasaran serta pemasar.

Konsep ini dapat dilihat digambarkan dalam gambar gambar berikut : 


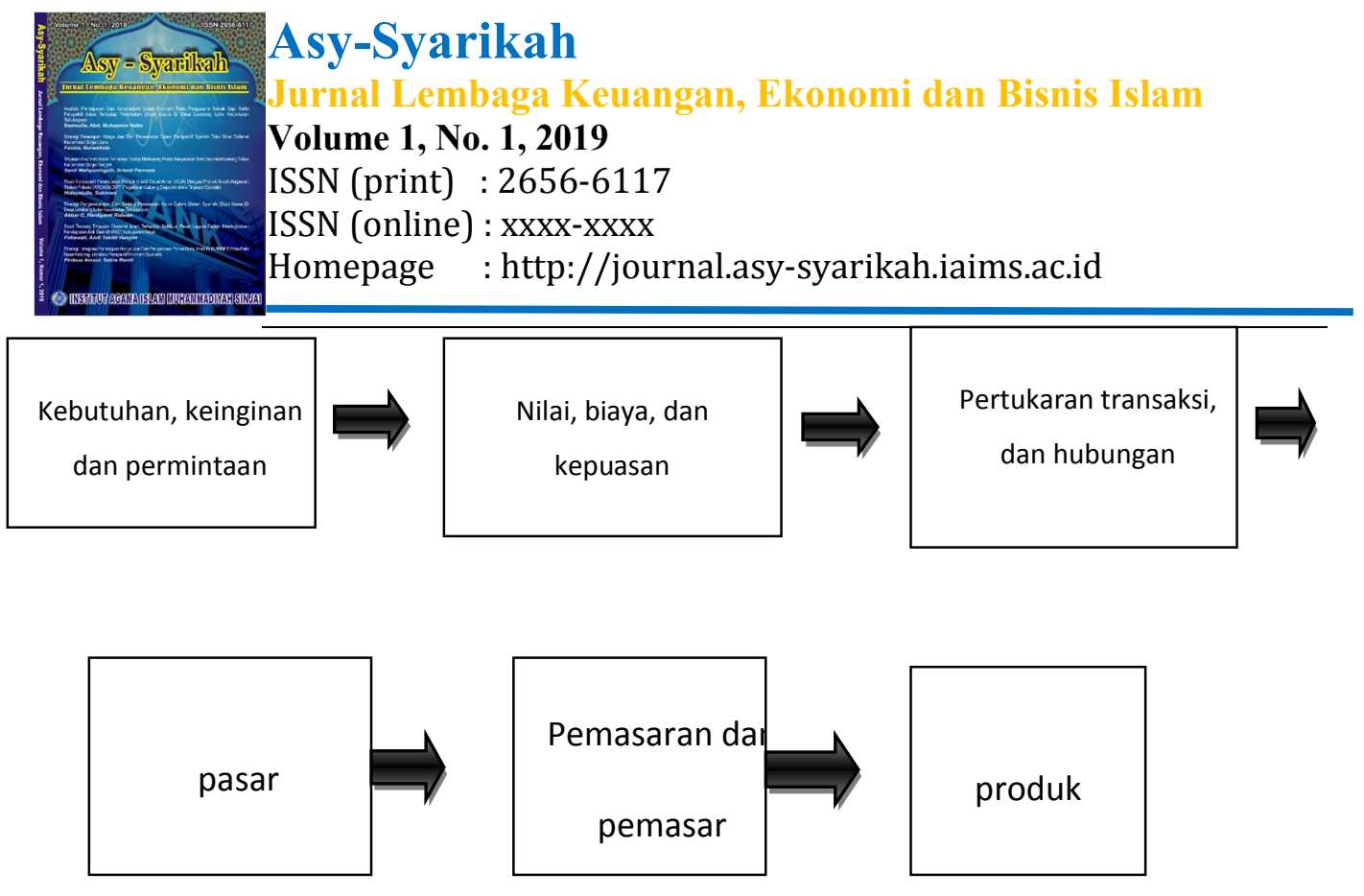

Gambar 2.1. Konsep Inti Pemasaran.

2. Proses pemasaran

Menurut Kotler dan Armstrong menggambarkan model sederhana dari lima langkah proses pemasaran berikut:

a. Langkah pertama, dari proses pemasaran adalah memahami pasar dan kebutuhan serta keinginan pelanggan. Kebutuhan adalah keadaan dan perasaan kekurangan. Keinginan adalah kebutuhan manusia yang terbentuk oleh budaya dan kepribadian seseorang. Permintaan adalah keinginan manusia yang didukung oleh daya beli.

b. Langkah kedua, merancang strategi pemasaran yang digerakkan oleh konsumen.

c. Langkah ketiga, membangun program pemasaran terintegrasi yang memberikan nilai unggul.

d. Langkah keempat, membangun lingkungan yang menguntungkan dan menciptakan kepuasan pelanggan.

e. Langkah kelima, menangkap nilai dan pelanggan untuk menciptakan keuntungandan ekuitas pelangggan.

3. Faktor strategi penting dalam strategi pemasaran

Ada tiga pilar utama yang diperlukan untuk mewujudkan visi dan misi strategi pemasaran yang baik. Ketiga pilar utama itu ialah.

a. Seluruh aspek strategi harus berfilosofi pada satu tujuan yaitu diferentitation strategi atau strategi pembeda yang jelas dengan produk pesaing dan bukan hanya pada aspek menjual saja. 


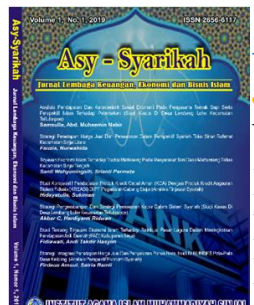

Asy-Syarikah

Jurnal Lembaga Keuangan, Ekonomi dan Bisnis Islam

Volume 1, No. 1, 2019

ISSN (print) : 2656-6117

ISSN (online) : xxxx-xxxx

Homepage : http://journal.asy-syarikah.iaims.ac.id

b. Strategi pemasaran yang efektif bukan hanya beriorientasi pada omzet penjualan atau nilai yang dijual saja tetapi lebih pada kekuatan merek anda di pasar.

c. Strategi pemasaran penting lainnya adalah menciptakan kekuatan merek produk (branding) dengan strategi pembeda (diferentiation) yang jelas.

\section{Hasil Penelitianyang Relevan}

a. Indri Pertiwi Pohan, Dalam skripsi yang berjudul "Analisis Nilai Tambah Dan Pemasaran Kopra (Studi Kasus Desa Silo Baru Kecamatan Silau Laut, Kabupaten Asahan)". Hasil penelitiannya menyimpulakan bahwa nilai tambah yang diperoleh petani tergolong tinggi yakni sebesar $96 \%$, nilai tambah yang diperoleh dari pengelohan kelapa kupas menjadi kopra tergolong rendah yakni $24 \%$, nilai tambah yang diperoleh dari pengelohan kopra menjadi tepung tergolong rendah yakni sebesar $18,22 \%, \mathrm{n}$ ilai tambah yang diperoleh dari pengolahan kopra menjadi minyak tegolong tinggi yakni sebesar $64,69 \%$. Hasil penelitian juga menunjukkan bahwa terdapat 2 saluran pemasaran didaerah penelitian. Biaya pemasaran tertinggi terdapat pada saluran pemasaran II ( petani - pedagang pengumpul -npengumpul pedagang besar ) sebesar Rp. 2.172,24/kg, sedangkan biaya pemasaran terendah adalah terdapat pada saluran pemasaran II ( petani - pedagang besar ) sebesar Rp. 1.605,07/kg. Saluran tataniaga yang ada sudah efisien, dimana saluran pemasaran II lebih efisien dari saluran pemasaran I karena pemasarannya lebih pendek dan biayanya lebih kecil daripada saluran pemasaran I.

b. Buzalmi, Dalam skripsi yang berjudul 'Analisi Pendapatan, Pemasaran Dan Strategi Pengembangan Agribisnis Kelapa Di Kabupaten Indragiri Hilir'’. Hasil penelitiannya penyimpulkan bahwa kelapa merupakan komoditas utama bagi prokonomian kabupaten indragiri hilir. Pada tahun 2002 total luas arela kelapa didaerah ini seluas 438,560 hektar dengan produksi 457.998 ton setara kopra. Dari luas areal tanaman kelapa tersebut, tanaman menghasilkan hanya seluas 281,714 hektar berarti produktivitasnya baru sekitar 1,63 ton/hektar/tahun. Rendahnya produktifitas dan harga kopra di tingkat petani sangat mengancam nasib petani kelapa di kabupaten indrgiri Hilir. Agar petani bisa meningkatkan kesejatrahannya, perlu menata strategi yang baik yang tepat untuk meningktkan pendapatan petani, terutama pada sub-sistem produksi dan pemasaran hasil produksinya. Dari sub-sistem produksi, pendapatan petani berdasarkan bagi hasil peenjualan produksi kopra aantara petani dan pekerja 


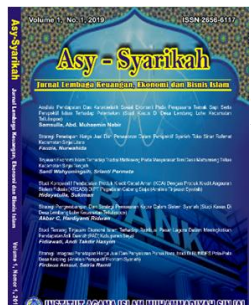

Asy-Syarikah

Jurnal Lembaga Keuangan, Ekonomi dan Bisnis Islam

Volume 1, No. 1, 2019

ISSN (print) : 2656-6117

ISSN (online) : xxxx-xxxx

Homepage $\quad:$ http://journal.asy-syarikah.iaims.ac.id

dengan harga Rp. 1.600.000/ton baru sekitar Rp 1.648.000/hektar/pertahun. Untuk empat kali panen/tahun berarti pendapatan petani kelapa sekitar Rp. 412.00/panen. Jika pendapatan petani bisa mencapai kondisi ideal 3 ton/hektar/tahun, pendapatan petani bisa mencapai Rp. 2.959.00/hektar/tahun yaitu sebesar dengan Rp. 739.875/panen. Ditinjau dari distribusi marjin untuk kelapa dan kopra di kabupaten indrigiri Hilir, tenyata pola pemasaran untuk kelapa butiran belum efisien karena marjin terbesar pemasaran berada pada pedagang pengumpul pabrib yaitu sebesar $28,57 \%$, sementara marjin pesaran pada pedagang pengumpul desa relatif kecil yaitu $15,31 \%$, begitu juga dengan proporsi harga ditingkat petani kelapa terhadap harga akhir relatif rendah yaitu $56,12 \%$ berbeda dengan kasus pemasaran kopra keadaannya relatif baik dan sfisien bila ditinjaiu dari seberang marjinnya. Seberang marjinnya cenderung mendekati yaitu $13,89 \%$ untuk pedagang pengumpul desa dan $11.11 \%$ untuk pedagang pengumpul babrik. Sama halnya dengan proporti harga kopra ditingkat petani kelapa terhadap harga akhir yaitu cukup tinggi yakni 75\%. Dalam pengembangan agrobisnis kelapa pada sub-sistem produksi dan pemasaran hasil produksinya, terdapat empat startegi yang dikembangkangkan strategi tersebut adalah startegi SO (S1, 01 dan 03), startegi ST (S2, S3 dan T4), startegi WO (W2, W3 dan O2), dan strategi WT (W1, T1 dan T3).

c. Putri Agung Lestari dalam penelitiannya tentang Analisis Strategi Pemasaran pada Usaha Kecil Menengah Pakaian Muslim (Studi Kasus pada UKM Pakaian Muslim Galis Design, Bogor, Jawa Barat) pada tahun 2010 menyatakan bahwa Penelitian ini, teridentifikasi enam elemen yang berpengaruh pada penyusunan strategi pemasaran Galis Design, yaitu elemen kemampuan finansial, selera konsumen, tingkat persaingan, karakteristik pasar, kualitas produk, dan saluran distribusi pemasaran. Elemen utama yang dipertimbangkan dalam penyusunan strategi pemasaran Galis Design adalah kualitas produk dengan bob $(0,248)$. Elemen kedua yang berpengaruh adalah saluran distribusi pemasaran dengan bobot $(0,222)$, selanjutnya selera konsumen menempati prioritas ketiga dengan bobot $(0,220)$, karakteristik persaingan prioritas keempat $(0,115)$, kemampuan finansial menempati prioritas kelima $(0,103)$ dan tingkat persaingan menempati prioritas terakhir dengan nilai bobot sebesar $(0,092)$. 


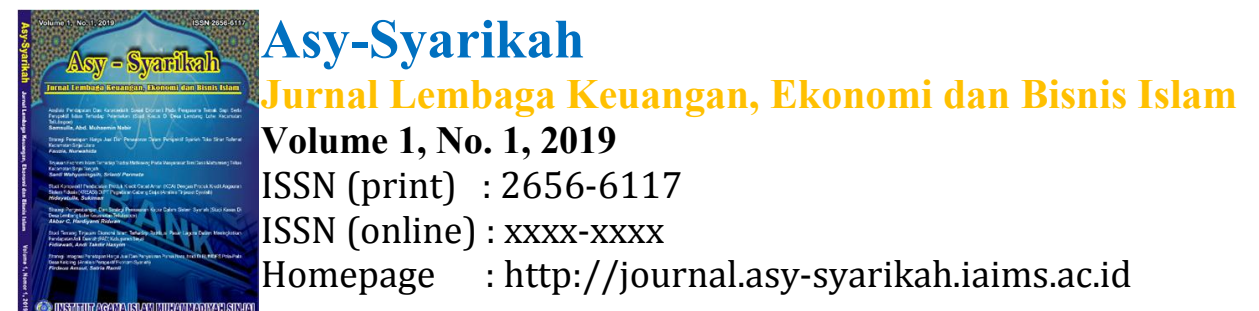

4. Metode Penelitian

\subsection{Jenis dan Pendekatan Penelitian}

Jenis penelitian yang digunakan adalah penelitian kualitatif. Penelitian kualitatif adalah merupakan sebuah metode penelitian yang digunakan dalam mengungkapkan permasalahan dalam kehidupan kerja Organisasi Pemerintah, Swasta, Kemasyarakatan, Kepemudaan, Perempuan, Olahraga, Seni dan Budaya, sehingga dapat dijadikan suatu kebijakan untuk dilaksanakan demi kesejahteraan bersama. Pendekatan kualitatif dengan fokus penelitian pada strategi pengembangan dan pemasaran kopra.

\subsection{Metode Pengumpulan Data}

a. Wawancara

Wawancara adalah suatu percakapan yang diarahkan pada suatu masalah tertentu dan merupakan proses Tanya jawab lisan dimana dua orang atau lebih berhadapan secara fisik. Wawancara merupakan bentuk pengumpulan data yang paling sering digunakan dalam penelitian kualitatif.

Wawancara pada penelitian kualitatif merupakan pembicaraan yang mempunyai tujuan dan didahului beberapa pertanyaan informal. Wawancara adalah suatu percakapan yang diarahkan pada suatu masalah tertentu; ini merupakan proses Tanya jawab lisan, dimana dua orang atau lebih berhadap-hadapan secara fisik. Adapun subjek wawancara adalah pelaku produksi kopra dan pedagang kopra didesa Lembang Lohe Kecamatan Tellulimpoe.

b. Dokumentasi

Kata dokumen berasal dari bahasa latin yaitu docere, bearati mengajar. pengertian dari kata dokumen ini seringkali diguanakan para ahli dalam dua pengertian, yaitu pertama, bearati sumber tertulis bagi informasi sejarah sebagai kebalikan dari pada kesaksian lisan, artefak, peninggalan-peninggalan terlukis, dan petilasan-petilasan arkeologis. Pengertian kedua diperuntukkan bagi surat-surat resmi dan surat-surat Negara, seperti surat perjanjian, undang-undang, hibah, konsesi, dan lainnya. Lebih lanjut, Gottschalk menyatakan bahwa dokumen (dokumentasi) dalam pengertiannya yang lebih luas berupa setiap proses pembuktian yang didasarrkan atas jenis sumber apapun, baik itu yang bersifat tulisan, lisan gambaran, atau arkeologis.

\subsection{Instrument Penelitian}

Dalam penelitian lapangan dipergunakan instrumen penelitian dengan metode yang dipergunakan dalam pengumpulan data. Adapun pengertian instrumen penelitian adalah alat 


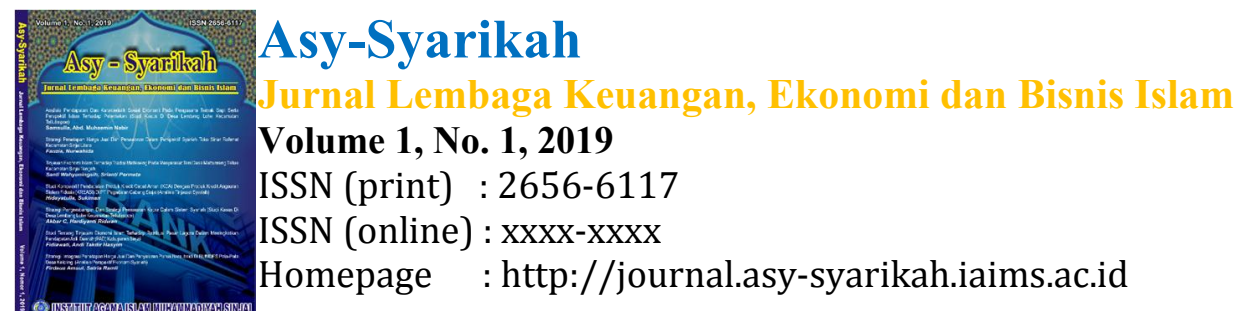

untuk memperoleh data. Agar pengumpulan data berlangsung efektif perlu ditunjang oleh alat pengumpul data yang baik pula. Adapun instrumen yang digunakan dalam penelitian ini adalah sebagai berkut:

a. Lembar Wawancara

Lembar wawancara adalah pedoman yang digunakan dalam kegiatan wawancara. Pedoman wawancara ini berisi sejumlah pertanyaan-pertanyaan yang berhubungan dengan masalah yang dibahas dalam skripsi ini. Pertanyaan tersebut merupakan acuan dasar dan dapat dikembangkan lebih jauh (fokus) ke objek yang dikehendaki.

b. Lembar Dokumen

Lembar Dokumen adalah berupa catatan-catatan pelaku produksi Kopra dan pedagang pengumpul dalam strategi pengembangan dan pemasaran kopra diDesa Lembang Lohe Kecamatan Tellulimpoe.

\subsection{Teknik Pengolahan dan Analisis Data}

a. Collection data, merupakan pengumpulan data dalam penelitian kualitatif lebih di fokuskan selama proses penelitian di lapangan secara bersamaan dengan pengumpulan data.

b. Reduksi data diartikan sebagai proses pemilihan, pemokusan, penyederhanaan, abstraksi, dan pentransformasian "data mentah" yang terjadi dalam catatan-catatan lapangan tertulis di lapangan. Sebagaimana kita ketahui, reduksi data terjadi secara kontinu melalui kehidupan suatu proyek yang diorientasikan secara kualitatif.

c. Display data/penyajian data, sebagai suatu kumpulan informasi yang tersusun yang membolehkan pendeskripsian kesimpulan dan pengambilan tindakan.

d. Verifikasi data/penarikan data, sebagai penarikan dan verifikasi kesimpulan beserta penyusunan dan kebutuhan.

\section{Hasil Penelitian Dan Pembahasan}

\subsection{Strategi Pemasaran Kopra Didesa Lembang Lohe Kacamatan Tellulimpoe.}

Kopra merupakan putih lembaga dari buah kelapa segar yang dapat dikeringkan dengan metode konvensional mneggunakan sinar matahari langsung, pengeringan dengan pemanasan secara tidak langsung, dan pengeringan dengan udara vakum. Tataniaga kelapa pada umumnya memang perang penting atau merupakan faktor keberhasilan suatu usaha tani.

Dari beberapa hasil wawancara terkait dengan Pengelolaan kopra yang dilakukan didesa Lembang Lohe Kecamatan Tellulimpoe, petani kopra masih menggunakan 


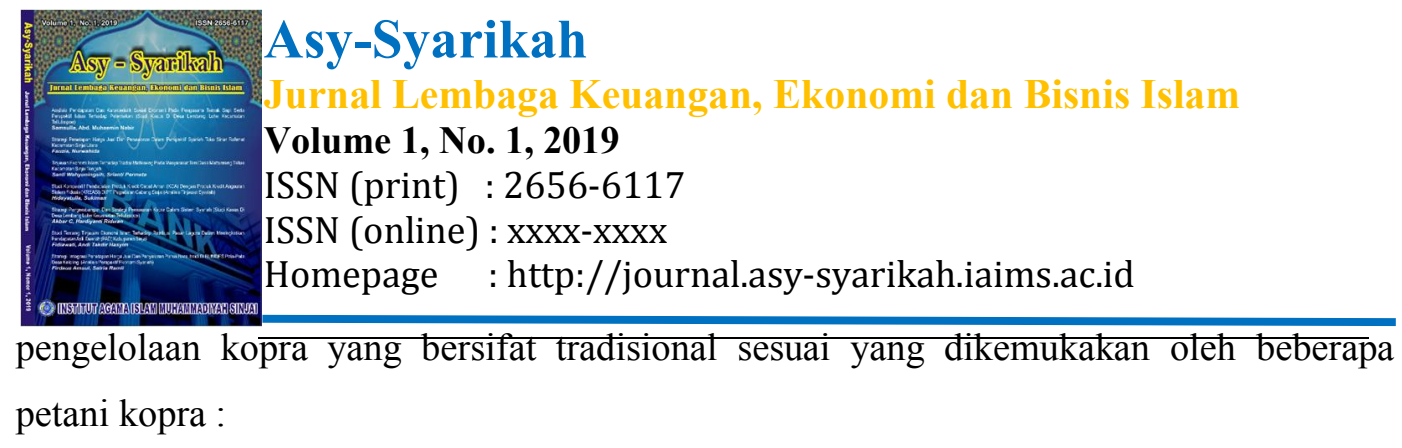

Saleha yang mengemukakan bahwa ada beberapa langkah dalam pengelolaan kopra yaitu kelapa yang sudah dipanjat dikupas sabutnya kemudian tempurung kelapa dikupas lalu diambil kelapanya dengan cara mencungkil keluar dari tempurungnya, lalu dijemur selama 2 sampai 3 hari.

Produk merupakan sesuatu yang diproduksi oleh tenaga kerja dari bahan menta menjadi barang jadi, yang dapat ditawarkan atau diperjualan belikan. Untuk mempertahankan daya saing terhadap produk yang ada, yaitu dengan cara menawarkan produk yang dapat memberikan jenis kepuasan kepada pelanggang, agar pelanggang tetap percaya bahwa produk kopra yang dihasilakan memiliki kualitas cukup baik. Maka petani kopraharus menciptakan kualitas yang cukup baik, untuk menciptakan kualitas yang baik maka harus dilakukan sesuai dengan langkah-langkah seperti yang dikemukakan oleh petani kopra,

Kunca mengemukakan bahwa untuk memperoleh kualitas kopra yang baik, maka bahan yang digunakan harus kelapa yang baru di ambil dari pohonnya langsung, dan memilih jenis kelapa yang memiliki kualitas baik, kemudian di jemur dibawa matahari langsung.

Sedangkan menrut lampe, ia mengatakan bahwa dalam memeproduksi kualitas kopra, kelapa yang digunakan harus memilih jenis kelapa yang sangat kering dan tidak dicampur dengan kelapa yang sudah tumbuh akar di sabut. Distribusi adalah cara perusahaan menyalurkan barangnya, melalui dari tangan perusahaan sampai ketangan konsumen akhir.

Strategi distribusi penting dalam upaya perusahaan melayani konsumen tepat waktu dan tepat sasaran, keterlambatan dalam penyaluran mengakibatkan perusahaan kehilangan waktu dan kualitas barang serta diambilnya kesempatan oleh pasaing.

Menurut Lesso sistem penyaluran yang digunakan yaitu dengan cara menyalurkan produk kopra ke pedagang pengumpul, karna untuk menyalurkan langsung kepasar harus memiliki strategi tertentu dan memakan waktu 2 atau 3 hari baru bisa menyalurkan, berbeda ketika menyalurkan langsung ke padagang pengumpul, hanya memanggil pedagang atau pedagang pengumpul langsung ketempat untuk mengambil prodok yang sudah di hasilkan. 


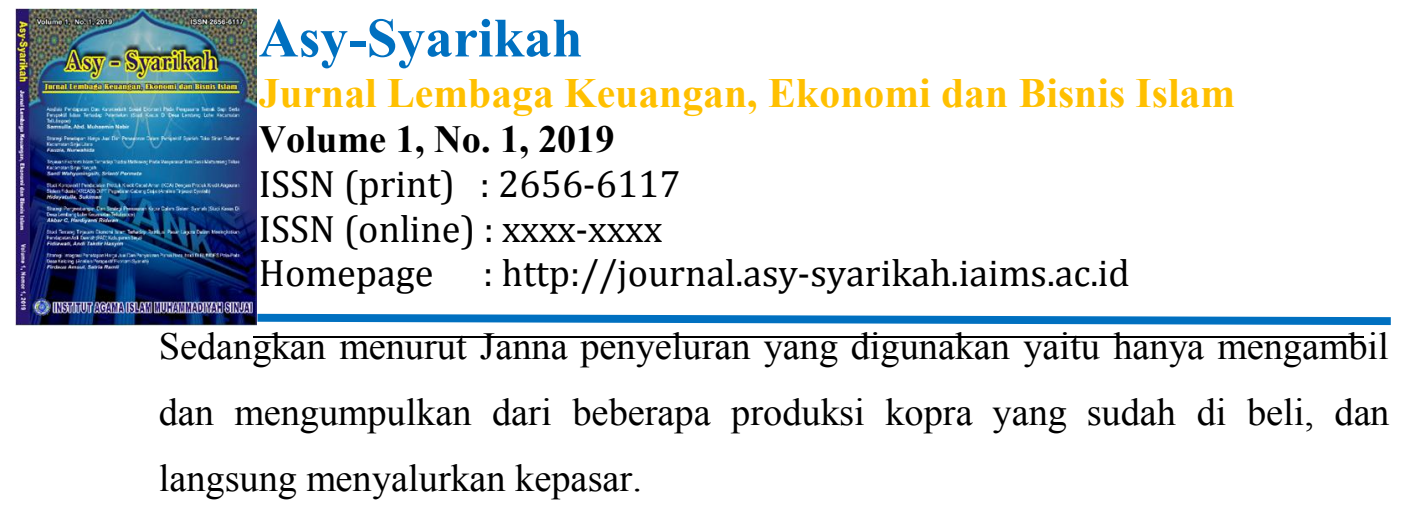

Harga merupakan sejumlah nilai yang harus dibayar konsumen untuk membeli barang atau jasa yang ditawarkan. Harga jual suatu produk perlu ditetapkan, dimaksudkan untuk memperoleh laba. Penentuan harga menjadi sangat penting, mengingat harga merupakan satu penyebab laku tidaknya produk barang atau jasa yang ditawarkan.

Penentuan harga merupakan satu keputusan yang paling sulit untuk suatu usaha baru adalah harga yang tepat untuk produk atau jasa.produk atau jasa mungkin ditetapkan pada harga tinggi untuk mempertahankan citranya. Dalam keputusan penentuan harga, faktor lain harus dipertimbangkan seperti biaya, diskon, pengangkutan dan laba. Penetuan harga tergantung pada permintaan produk karena kemampuan untuk membeli bahan dalam jumlah besar mengurangi biaya. Dari hasil wawancara dari sala satu petani(produksi) kopra mengemukakan bahwa

Kine mengatakan bahwa harga produksi kopra tergantung dari permintaan penawaran pasar, ketika permintaan dan penawaran pesar naik, maka harga produk kopra juga naik, jika harga permintaan dan penawaran pasar naik maka harga produk kopra juga naik, jadi kesimpulanya adalah harga produk kopra tidak menentu kadang naik, dan kadang turun, tidak menetap.

Pemasaran merupakan sesuatu system total dari kegiatan bisnis yang dirancang untuk merencanakan, menentukan harga, mempromosikan dan mendistribusikan barangbarang yang dapat memuaskan keinginan dan jasa baik kepada konsumen saat ini mauapun konsumen potensial. Ada beberapa mencakup kegiatan pemasaran yaitu :

a. Menyediakan dan mengetahui apa yang dinginkan konsumen,

b. Kemudian merencanakan dan mengembangkan sebuah produk atau jasa yang akan memenuhi keinginan konsumen.

c. Dan kemudian memutuskan cara terbaik untuk menetukan harga, memepromosikan dan mendistribusikan produk atau jasa.

Berdasarkan hasil wawancara yang didapatkan terkait dengan sistem pemasaran kopra didesa lembang lohe sesuai yang dijelaskan oleh beberapa petani kopra yaitu : 


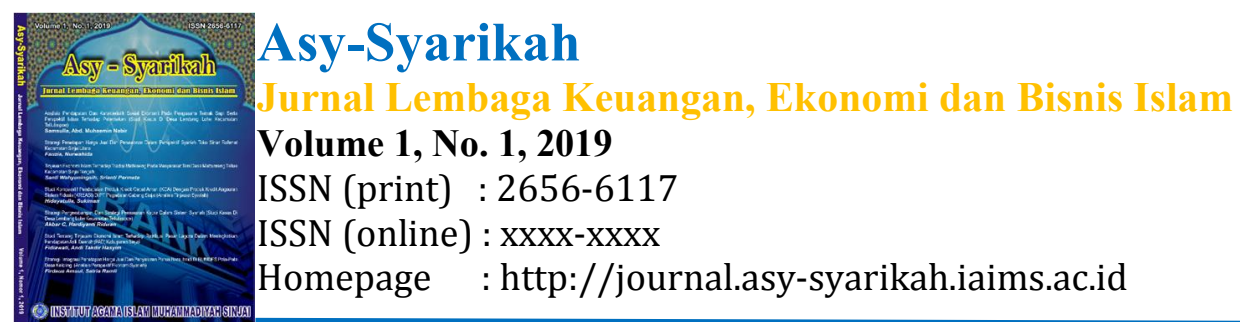

Menurut hasil wawancara dari Cini bahwa sistem yang digunakan dalam system pemasaran kopra hanya memasarkan langsung kepada pedagang yang terdekat, karna harga di pasar dengan harga yang ditawarkan oleh pedagang tidak jauh beda.

Sedangkan menurut Hasni mengatakan bahwa system pemasaran yang digunakan yaitu dengan cara memasarkan langsung kepasar, karna lebih leluasa untuk negosiasi sesame pedagang.

Konsep mekanisme pasar dalam Islam dibangun atas prinsip-prinsip sebagai berikut:

a. Ar-Ridha, yakni segala transaksi yang dilakukan haruslah atas dasar kerelaan antara masing-masing pihak (freedom contract). Hal ini sesuai dengan al-Qur'an Surat anNisa' ayat 29 yang artinya:

"Hai orang-orang yang beriman, janganlah kamu saling memakan harta sesamamu dengan jalan yang batil, kecuali dengan jalan perniagaan yang berlaku dengan suka sama suka di antara kamu. dan janganlah kamu membunuh dirimu; Sesungguhnya Allah adalah Maha Penyayang kepadamu."

b. Berdasarkan persaingan sehat (fair competition). Mekanisme pasar akan terhambat bekerja jika terjadi penimbunan (ihtikar) atau monopoli. Monopoli setiap barang yang penahanannya akan membahayakan konsumen atau orang banyak.

c. Kejujuran (honesty), kejujuran merupakan pilar yang sangat penting dalam Islam, sebab kejujuran adalah nama lain dari kebenaran itu sendiri. Islam melarang tegas melakukan kebohongan dan penipuan dalam bentuk apapun. Sebab, nilai kebenaran ini akan berdampak langsung kepada para pihak yang melakukan transaksi dalam perdagangan dan masyarakat secara luas.

d. Keterbukaan (transparancy) serta keadilan (justice). Pelaksanaan prinsip ini adalah transaksi yang dilakukan dituntut untuk berlaku benar dalam pengungkapan kehendak dan keadaan yang sesungguhnya.

Berdasarkan beberapa penjelasan di atas, strategi pemasaran kopra dalam sistem syariah di desa lembang lohe kecamatan tellulimpoe, dan berdasarkan hasil penelitian, semuanya bisa dikatakan sesuai dengan system syariah, karna bahan yang digunakan 


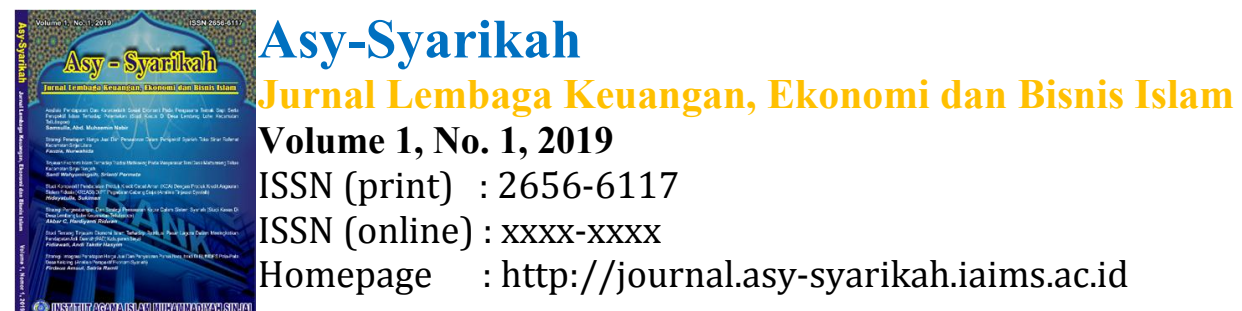

tidak ada yang mengandung kecurangan, hasil curian dan lain-lain, yang bertentangan dengan syariah. Sehingga sesuai dengan syariat islam, dan tidak merugikan pihak lainnya dalam usaha ini.

\subsection{Strategi Pengembangan Kopra Didesa Lembang Lohe}

Pengembangan usaha merupakan Tugas dan proses persiapan analitis tentang peluang pertumbuhan potensial, dukungan dan pemantauan pelaksanaan peluang pertumbuhan usaha, tetapi tidak termasuk keputusan tentang strategi dan implementasi dari peluang pertumbuhan usaha.Strategi Pengembangan Bisnis merupakan keseluruhan usaha termasuk perencanaan, cara, teknik, media, dan taktik yang digunakan dalam mengembangkan bisnis sehingga tujuan usaha atau bisnis dapat tercapai. Dalam strategi mengembangkan usaha, perlu diperhatikan faktor-faktor tentang:

a. Kebutuhan modal untuk ekspansi hingga tumbuh.

b. Analisa risiko keagagalan usaha

c. Analisa tingkat keuntungan

d. Tren pasar dan berapa lama pertumbuhan bisnisnya.

e. Tingkat kesulitan yang dihadapi.

f. Faktor-faktor pendukung dan penghambat

g. Kebutuhan SDM dan keterampilannya.

Dalam hasil wawancara beberapa produksi kopra/petani kopra mengatakan bahwa :

Kunca mengatakan bahwa untuk mengembangkan produk kopra yang ada didesa lembang lohe, bahan mentah harus betul-betul dipertahankan agar tidak kekurang, dan pohon kelapa setidaknya ditambah lagi.

Sedangkan yang dikatakan cini bahwa untuk mengembangkan produk kopra didesa lembang lohe kecamatan tellulimpoe, masyarakat harus memanfaatkan kelapa karing dengan sebaik-baiknya, dan dijadikan kopra untuk mempertahankan ciri khas produksi daerah desa lembang lohe, sebagai sala satu penghasil kopra yang berkembang.

Dalam pengembangan usaha produksi kopra pasti tidak lepas dari kendala-kendala. Dan dari beberapa petani/produksi kopra berpendapat bahwa :

Lampe mengatakan bahwa kendala yang dialami untuk mengembangkan kopra didesa lembang lohe kecamatan tellulimpoe yaitu banyaknya masyarakat yang 


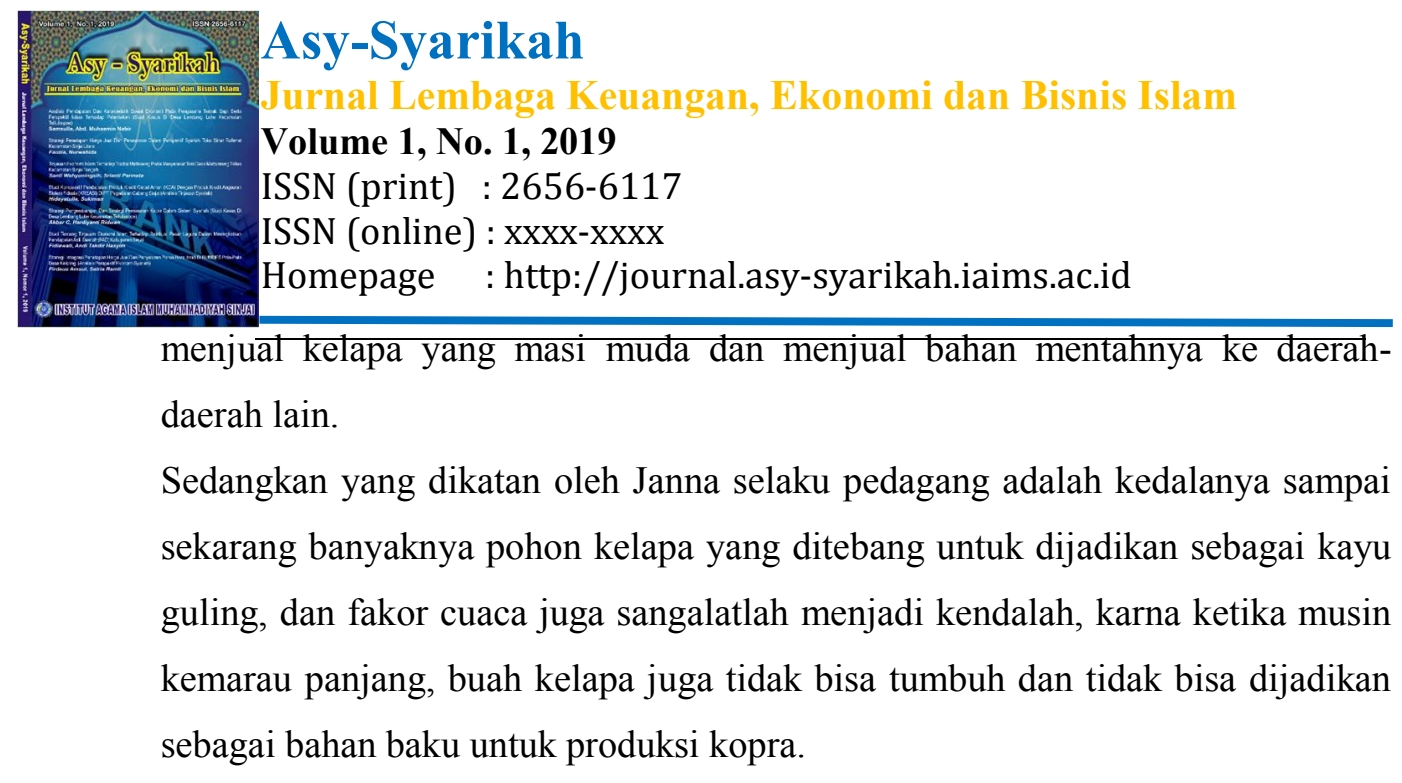

Pengembangan kpopra didesa lembang lohe dapat simpulkan, bahwa strategi pengembangan kopra sesuai denga syariah, karna tidak ada factor.

\section{Daftar Pustaka}

A.R. Ghazaly Dkk,Fiqh Muamalat, Cet. 1; Jakarta: Prenadamedia, 2010.

Abdullah Tamri dan Tantri Francis, Manajemen Pemasaran, Ed. I. Cet. IV ; Jakarta : PT. Raja Grafind Persada, 2015.

Buzalmi, Sekolah Pasca Sarjana Institut Pertanian Bogor. Analisi Pendapatan, Pemasaran Dan Strategi Pengembangan Agribisnis Kelapa Di Kabupaten Indragiri Hilir. 2004.

Basri Moding, Pemasaran Strategi, Cet. I ; Makassar : PT. Umitoha Ukhuwa Grafika. 2012.

Emzir, Metodologi Penelitian Kualitatif Analisis Data, cet: I, Jakarta: PT Raja Grafindo Persada, 2010

Geoffrey E. Meredith, Dkk. Kewirausahaan teori dan praktek.Cet. VI ; Jakarta : Cv. Taruna Grafica. 2000.

Hendi Suhendi, Figh Muamalah, Cet. IX; Jakarta: PT Raja Grafindo Persada, 2014.

Hendro, Dasar-Dasar Kewirausahaan, Jakarta : Erlangga, 2011.

Https://Id.Wikipedia.Org/Wiki/Kopra. di Akses pada Tgl 28 Juni 2017

Kasmir, Kewirawusahaan, Ed. I-2 ; Jakarta : PT Raja Grafindo Persada, 2007.

Kasmir, kewirausahaan, Cet. IX ;Jakarta : Rajawali Pers, 2013 


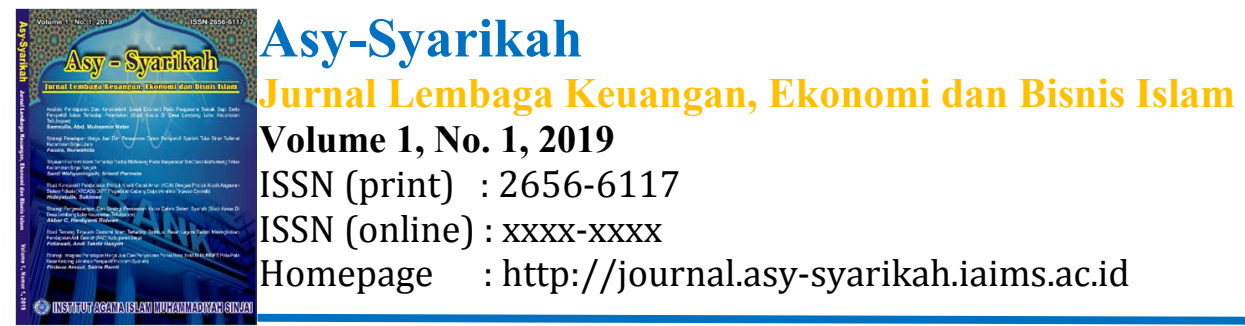

Kementrian Agama Republik Indonesia, Al-Qur'an dan Terjemahan, Jakarta: Penerbit Safira, 2014.

Masykur Wiratmo, Pengantar Kewiraswastaan Kerangka Dasar Memasuki dunia Bisnis, ED. I. CET. I ; Yogyakarta : BPFE-Yogyakarta, 2002.

Muh. Fauzan januari, Pengantar Hokum Islam Pranata Sosial,Cet. I ;bandung : Cv. Pustaka Setia. 2013.

Pertiwi Pohan Indri. Program Studi Agrobisnis Fakultas Pertanian Universitas Sematera Utara Medan 2013. Analisis Nilai Tambah Dan Pemasaran Kopra Studi Kasus Desa Silo Baru Kecamatan Silau Laut, Kabupaten Asahan.

Putri Safrilia, https://id.wikipedia.org/wiki/Kopra. di Akses Pada Tanggal 28 Juni 2017.

Sukardi, MetodologiPenelitianPendidikan, Cet. XIV; Jakarta: PT BumiAksara, 2015.

Sofjan Assouri, Manajemen Pemasaran Dasar, Konsep Dan Strategi, Cet. XIII ; Jakarta : PT. Rajagrafindo, 2014,

Uli Warlia Cece, Analisi Marjin Niaga Kopra Di Desa Punggur Kecil Kecamatan Sungai Kakap Kabupaten Kubu Raya, Universitas Pasca Bakti Fakultas Pertanian Pontianak, 2013. 


\begin{tabular}{|c|c|}
\hline 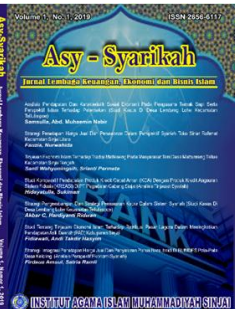 & $\begin{array}{l}\text { Asy-Syarikah } \\
\text { Jurnal Lembaga Keuangan, Ekonomi dan Bisnis Is lam } \\
\text { Volume 1, No. 1, 2019 } \\
\text { ISSN (print) : } 2656-6117 \\
\text { ISSN (online) : xxxx-xxxx } \\
\text { Homepage : http://journal.asy-syarikah.iaims.ac.id }\end{array}$ \\
\hline
\end{tabular}

